\begin{tabular}{|c|c|c|c|c|}
\hline Submission & Review Process & Revised & Accepted & Published \\
\hline $17-08-2020$ & $26-08$ s/d 24-11-2020 & $28-12-2020$ & $30-12-2020$ & $31-12-2020$ \\
\hline
\end{tabular}

Jurnal Studi Sosial dan Politik, Vol. 4, No. 2, December 2020 (135-146)

ISSN 25978756

e ISSN 25978764

Jurnal Studi Sosial dan Politik Published by: FISIP Universitas Islam Negeri Raden Fatah Palembang

\title{
The Relationship Between Religion and the State for the Sovereignty of the NKRI Study of Suryalaya TQN Murshid Thought in the Tanbih Text
}

\author{
Dodo Widarda \\ Fakultas Ushuluddin dan Pemikiran Islam UIN SGD Bandung \\ Email: dodowidarda@uinsgd.ac.id
}

\begin{abstract}
The research aims to search and find the relationship between religion and the state in the Text of the Tanbih of the Tarekat Qodiriyyah wa Naqsyabandiyyah (TQN) Suryalaya. This type of research is qualitative research through factual historical research on manuscript texts with the Philosophy Research Methodology. In the Tanbih Text originating from Sheikh Abdullah Mubarak bin Nur Muhammad (Abah Sepuh) and later popularized by Sheikh Ahmad Shohibul Wafa 'Tajul' Arifin (Abah Anom) the relationship between religion and the state has significant significance and serves as a guide for community and state life for the brothers TQN. In addition to developing Islamic values, Tanbih directed the brothers to develop a feeling of love for the motherland. The conclusion of this research, there is a strong relationship between religion and the state in the Tanbih Text and can be the basis for maintaining the sovereignty of the NKRI with a strong religious perspective. This study provides recommendations for further research related to the relationship of religion with the state to strengthen the mandate of Indonesians amid the development of various ideologies that threaten state sovereignty.
\end{abstract}

Keywords: religion, state, TQN, tanbih text, NKRI sovereignty

\begin{abstract}
Abstrak
Penelitian ini bertujuan untuk mencari dan menemukan keterkaitan antara agama dan negara dalam Teks Tanbih Tarekat Qodiriyyah wa Naqsyabandiyyah (TQN) Suryalaya. Jenis penelitian ini adalah penelitian kualitatif melalui penelitian sejarah faktual pada teks naskah dengan Metodologi Penelitian Filsafat. Dalam Naskah Tanbih yang bersumber dari Syekh Abdullah Mubarak bin Nur Muhammad (Abah Sepuh) dan kemudian dipopulerkan oleh Syekh Ahmad Shohibul Wafa 'Tajul' Arifin (Abah Anom) hubungan antara agama dan negara memiliki arti penting dan menjadi pedoman kehidupan bermasyarakat dan bernegara untuk ikhwan TQN. Selain mengembangkan nilai-nilai keislaman, Tanbih mengarahkan para ikhwan untuk menumbuhkan rasa cinta tanah air. Kesimpulan dari penelitian ini, terdapat hubungan yang kuat antara agama dan negara dalam Teks Tanbih dan dapat menjadi dasar untuk menjaga kedaulatan NKRI dengan perspektif agama yang kuat. Kajian ini memberikan rekomendasi untuk penelitian lebih lanjut terkait
\end{abstract}


hubungan agama dengan negara untuk memperkuat amanah keindonesia di tengah berkembangnya berbagai ideologi yang mengancam kedaulatan negara.

Keywords :agama, negara, TQN, tanbih text, kedaulatan NKRI

\section{INTRODUCTION}

The relationship between religion and the state will have relevance to continue to be discussed as a discourse related to the relationship between Islam and politics. The fact that occurs in the current political situation in Indonesia, the relationship between religion and the state is always a matter of lengthy debate because there are two parties with different desires related to the basics of managing the political system, between those who want a theocracy system and those who accept the democratic system. The continuity of the movement that aspires and fights for the Darul Islam Indonesian Islamic State (NII), is an example of a first party vis a vis a more subtle and flexible party to accept the democratic system within the frame of the Republic of Indonesia which is final while filling it with the spirit and Islamic values . Abah Sepuh and Abah Anom as murshid of TQN as stated in the Tanbih Text, make religion with this country two complementary components and show integral evidence that Sufism is very important in making ethical and pro politics towards society (Rohimat, 2017), and Abah Anom itself, in social relations and statehood always adheres to the principle of Tanbih and the principles of TQN goals that are inherited by his father (Misbach, 2018) in which there are ideas and concepts of harmony in the form of concepts that come from the process of meeting between traditional values and universality values Islam (Hidayat, 2016).

If traced to previous research, then there are various findings that have very strong relevance to this research. The study entitled "The Development of the Qadiriyyah-Naqshabandiyyah Congregation in the Suryalaya Islamic Boarding School" conveys an important point that must be mentioned that the Abah Sepuh had spread the Qadiriyyah wa Naqshbandiyyah Order in secret, which at that time was banned by the Dutch government; and indeed he never went to jail for these activities. During his leadership period, Suryalaya Islamic Boarding School made significant progress. Especially in teaching the Qadiriyya wa Naqshabandiyyah Tariqa to the Muslim community. During his life, he was ready to carry out the spread, not only in West Java but also in Central and East Java. The Abah Sepuh teachings that were written down and are always read at the events of the Manifesto of the Qadiriyya Naqshabandiyyah Suryalaya Congregation, namely Tanbih. In addition to Tanbih, Abah Sepuh also delivered a short message called a string of pearls which originally also spoke Sundanese and reads as follows: don't hate contemporary scholars, don't blame others for teaching, don't check other people's students, don't leave the place if offended, and must love those who hate you (Pujiastuti, 2016)

The study entitled "The Testament of Sufistic Education in the Text of the Blessing of the Murshid of the Qodiriyyah wa Naqsyabandiyyah Suryalaya (Study of the Thought of the Murshid of TQN Suryalaya)" emphasizes the importance of Sufistic education and is greatly needed by both individuals and the community. The moral character of a weak society must be further developed through various means namely vertical Sufi education is moral and worship of God, and horizontally is a good moral for fellow beings (Sayyi, 2017). What is written in the research is further strengthened by the acceleration in the research entitled, "Cultural Strategy of Suryalaya 
Pesantren-Tasikmalaya as Center of Islamic Studies in Facing Industrial Era 4.0" which successfully describes changes in all aspects of life now entering 4.0 eras, known as eras the fourth industrial revolution characterized by the dominance of proficiency in various fields. The article discussed the Suryalaya Islamic Boarding School cultural strategy as a center for amaliah as well as Islamic scientific studies developed in Indonesia during the 4.0 industry era. Various efforts have been made by Suryalaya Islamic boarding school in different fields of work, including the fields of religion, social, education, agriculture, health, environment and the state. Starting from teaching traditional tarekat, formal educational institutions, cooperative economic movements, and rehabilitation. Through methods based on Islamic values and local wisdom, Pesantren Suryalaya will be able to become the center of various qualification activities in the era of industry 4.0 without leaving the identity and integrity of a civilized nation (Gunawan, 2016).

The study entitled, "The Existence of Tarekat-Based Islamic Boarding Schools in the Global and Digital Era" has placed the strategic position of Suryalaya Islamic Boarding School as one of the Islamic boarding schools in Indonesia. Suryalaya is the oldest Sufistic Education Institution that makes an important contribution to educating the nation and improving its quality of life. There is an assumption that Sufi education can face all things from the process of globalization and digitalization. Through this research, the author explains that there are several reasons that the Sufistic Education Institute has the best influence in Islamic Education, especially in the internalization and identification of Islam to all nations to be close to Allah SWT. Associated with Tanbih is a practice that must be read both religiously and nationally. Moreover in Sheikh Abdul Qadir al-Jailani's Manaqib, which must be read after reading the verses of the Qur'an (Samsulbassar, 2018).

Another study entitled "Implementation of Suryalaya TQN Tanbih in Community Life at the Al-Kautsar Islamic Boarding School Pademawu Pamekasan " has placed this Tanbih as something very important in the life of the pesantren community. Tanbih as a cultural product becomes a demand and moral and ethical guidelines for the TQN brothers amid various changes in cultural values and the onslaught of globalization. As one of the observers of the teachings of AlKautsar Islamic Boarding School requires its students to always be guided by Tanbih TQN Suryalaya in every word and action. This is very helpful in creating a harmonious and peaceful social life in the boarding school environment (Baidlowi, 2020).

\section{RESEARCH METHODOLOGY}

Previous research provides a benefit for the sharpness of analysis and the development of a framework of thinking while placing this research position right in the middle of various existing studies and looking for a point of differentiation with previous results. What distinguishes it from previous research is the methodology used in this study is the philosophy research methodology. Thus, the formal object of this research is philosophical. Whereas the material object is the relation of religion and state in the TanbihText. The original text of the Tanbih Text is in Sundanese. Tanbih is the work of Sheikh Abdullah Mubarok bin Nur Muhammad (1846-1956) -Abah Sepuh-- whose contents are in the form of teachings, suggestions, and edicts written in Sundanese. The writings of Abah Sepuh were originally still beheaded and separated and in the form of handwriting, then collected and edited by K.H. Shohibulwafa T.A. (Abah Anom). Tanbih contains several Sundanese translations of the verses of the Qur'an. The translation reflects what message Abah Sepuh tried to convey, although on the other hand, he did not pay attention to the literal translation. Tanbih is 
written in poetic language, with many uses of alliteration and idiomatic expressions. The sentences are arranged aesthetically, containing elements of rhythm and the strength of words as a form of influence from the characteristics of traditional Sundanese expressions (Hidayat, 2016).

Based on the above framework, the formulation of this research is, the relationship between religion and the state can be studied philosophically. The question is how can the relationship between religion and the state in the Tanbih Text be placed as one of the pillars of the upholding of the Republic of Indonesia's sovereignty?

\section{RESULTS AND DISCUSSION}

\section{Religious Relations with the State in the Tanbih Text}

A Glimpse of Abah Sepuh. Abah Sepuh whose real name is Abdullah Mubarok Bin Nur Muhammad, born in 1836 in the village of Cicalung Bojongbenteng Pagerageung Tasikmalaya. His father's name was Raden Nur Muhammad alias Nurpraja or also known as Eyang Upas. While his mother named Emah. Abah Sepuh, since he was a child, sought enthusiasm for knowledge, focusing on studying jurisprudence and Arabic linguistics (nahwu-shorof) at Sukamiskin Islamic Boarding School in Bandung, then studying Sufism in Kalisapu Cirebon to Sheikh Tolhah for 23 years and at the same time studied at Sheikh Cholil Bangkalan Madura. In 1905 established a boarding school at the same time zawiyah special TQN practice in the upper bank of the river Citanduy. Now this place is known by the name Suryalaya, taken from the term Sunda which means Surya means the sun, and Laya which means the place of rising, so that the meaning of Suryalaya literally means the place where the sun rises. Abah Sepuh was heavily involved in the political arena, however the most prominent role was his success in persuading R.A.A Wiranata Kusumah to surrender and return to the Unitary State of the Republic of Indonesia, after a while serving as the leader of the Dutch State Pasundan State in West Java. R.A.A.'s Return Wiranata Kusumah perfected the integrity of the West Java region administratively as a province under the authority of the Republic of Indonesia

As for Abah Anom, he was born on January 1, 1915 and died on September 5, 2011. At the age of 18, Abah Anom was given the authority to become a Talqin representative by Murshid TQN Abdullah Mubarak. He studied Islam in depth in several major pesantren, such as in Carijur Cicariang, Jambudipa Pesantren and Gentur in Cianjur and practiced spiritual (riyadhoh) directly under the guidance of his father. He also sought knowledge in Bangkalan Madura with his brother H.A. Dahlan and KH. Fakih. Abah Anom married Euis Ru'yanah in 1938 at the age of 23. In the same year he went to Makkah to stay for 7 months to study Sufism and tarekat to a representative of the Abah Sepuh talqin named Sheikh Romli Garut who was residing in Jabal Qubaish near the city of Makkah. A year later in 1939, Abah Anom returned to Suryalaya and immediately helped Abah Sepuh to develop the Suryalaya pesantren.

In the context of defense of religion and the state, in 1945-1949 Abah Anom was also active in helping the war for independence. When Indonesia was in the Old Order in 1953, Abah Anom was officially appointed as the head of the Suryalaya Islamic Boarding School as well as the Talqin representative from Abah Sepuh. During the period 1953-1962, Abah Anom was active in assisting the Indonesian Armed Forces Council to fight against the Kartosuwiryo rebellion. During 19531995 actively assisted the government in its programs, such as agriculture, environment, education, 
economy, social, health, and politics with a very popular contribution was the establishment of Inabah as a mental rehabilitation center for drug addicts.

Tanbih is a will, message, guidance, warning, guidance from a Sheikh Murshid, born from a series of dialogues between the eternity of the universal and eternal word of God with local and actual conditions in Indonesia. Tanbih as a cultural product is the result of Abah Sepuh's long contemplation in understanding Islamic values with a frame of local wisdom. Tanbih was born from a high awareness of Abah Sepuh to frame various Divine messages in the present map so that it can be implemented and used as a guide by various levels of human beings with all its limitations that expect holy life and height on the side of its Creator. Tanbih is expected to be able to frame the lives of students in order to remain in effect as exemplified by it in everyday life (Samsulbassar, .2018)

This Tanbih begins with a prayer for all levels of society:

"This Tanbih is from Syaekhuna of the late Sheikh Abdullah Mubarak bin Nur Muhammad who resides in Patapan Suryalaya Kajembaran Rahmaniyah. His words to all male and female students, young and old alike: "May there be happiness, endowed with Allah Subhanahu Wata'ala eternal and eternal happiness and hopefully no rift will arise in our surroundings." ('Arifin, 1988)

The next prayer is aimed at the political elite symbolized by the leadership of the state (Rohimat, 2012):

"It is also hoped that the Leadership of the State will increase its glory and grandeur so that it can protect and guide all people in a safe, just and prosperous state of life and conscience." ('Arifin, 1988)

Abah prayed for the political elite to grow in glory and grandeur. Glory and grandeur can only be obtained by positioning the elite's image to remain positive. A noble country leader will surely be loved by his people. Glory will grow by itself which comes from the piety of the leader (Rohimat, 2012).

In this Tanbih, Abah ordered all his students to always obey religious and State regulations. This means that Abah wants to realize the rule of law that is truly upheld, not just formalities, but must be upheld with totality and justice (Rohimat, 2012):

"We are also a place where people ask about Tariqah Qadiriyyah wa Naqsabandiyah, sincerely giving a will to all students: be careful in everything not to do anything that is contrary to religious or state regulations." ('Arifin, 1988)

In the formulation of the Pancasila ideology and the 1945 Constitution, the substance of the Indonesian state is in the form of a religious nation state. The state does not deny the role of religion, nor does religion reject the existence of the state. Between religion and the state has an important role in the success of the ideals of Indonesian independence, which is to realize social welfare and educate the life of the nation and state in the container of the Unitary Republic of Indonesia (NKRI). (Dahlan, 2014). But there are also limits to obedience to the state so that the form of compliance 
must be in the right proportion, not absolute obedience. Obeying state regulations as long as they do not conflict with religious rules, and positions obeying religion take precedence over obeying the state. This shows if there is a conflict, then the religious regulations that must be prioritized (Rohimat, 2012)

"Obey both are appropriate, such is the attitude of humans who remain in the faith, specifically he can realize the willingness of Divine Divorate to prove that the commands in religion and the state." ('Arifin, 1988)

Implied by the sentence, Abah considered that the measure of one's faith could be seen from human ability to uphold the rule of law. Humans whose faith is weak tend to be negligent from carrying out religious and state commands. So every human being should repent and evaluate his faith. Moreover, Satan and human lust always invite people to disobey religion and state as mentioned in the next sentence:

"Insyafilah, students, do not be enticed by lust, influenced by the temptations of the devil, beware of the way of distortion of religious and state commands, so that you can examine yourself, in case you are attracted by the whisper of the devil who always sneaks in our hearts." ('Arifin, 1988)

Society as a political subject becomes an important element in political ethics. A harmonious society will make the country's condition more stable. Riots, chaos, uncontrolled demonstrations will trigger chaos, and political crises, and will be more dangerous if there is an economic crisis and social crisis. TQN Suryalaya anticipates that with gentle advice and can be understood by all elements of society. Within the community itself it is hoped that there is awareness to be able to maintain the stability of their harmony. People who are ethical, respect each other, respect each other, be humble, care for the poor, friendly to the weak, and friendly to strangers (Rohimat, 2012), as revealed in the following Tanbih:

"It is better to prove the virtues arising from holiness:

1. To people who are higher than us, both dlohir and mind, we must respect, that is how to live in harmony and mutual respect.

2. With others who are equal with us in everything, do not allow disputes to occur, on the contrary must be humble, work together in carrying out religious and state commands, do not lead to disputes and disputes, in case we are exposed to his word "Adzâbun 'Alem', which means suffering forever and ever from the world to the hereafter (hard-hearted body hard).

3. With respect to those who are under us, do not want to humiliate or act indecent, behave arrogantly, on the contrary must be compassionate with awareness, so that they feel happy and happy, do not feel afraid and wild, as if cut in their hearts, on the contrary must be guided by gentle advice that will give conviction in the path of goodness.

4. Towards the needy-poor, must be affectionate, friendly and sweet, be generous, and reflect that our hearts are aware. Try to feel ourselves, how painful it is in a state of lack, therefore do not be indifferent, only yourself are happy, because they become needypoor it is not their own will, but that is God's nature. " ('Arifin, 1888) 
In fact, TQN Suryalaya is a very fundamental religious group, in that aqidah is absolute and cannot be interfered with by other creeds. However, it turns out that strong faith will actually give birth to a spirit of high tolerance. This is evident from the mandatory orders from Abah to respect other religions as well as possible. There must be no disputes between religions, they must live in harmony and peace despite their different religions. So, when interfaith can live in harmony, the political life of this country will get along well. Even though Indonesia is predominantly Muslim, non-Muslim citizens are still given the same opportunity to be able to channel their political expression. This is political ethics in the form of tolerance that was initiated by Abah in his Tanbih. Abah bases this ethic on Al-Kafirun verse verse 6: "Your religion is for you, my religion is for me." However, Abah also limits interactions with non-Muslims with the term "don't mix". This means that the interaction is only limited to muamalah activities. The activities of creed, faith and worship must be separated:

"As for religious matters, it is up to their respective religions, remembering Surah Al Kafirun verse 6:" Your religion is for you, my religion for me ", It means that there is no dispute, we must live in harmony and peace, mutual respect, but never to intervene." ('Arifin, 1988)

Abah then guide all brothers in religious affairs not to participate, but in social, economic and political life, the TQN Suryalaya brothers must unite peacefully and tolerantly. Next Tanbih explained:

"Try to contemplate the saying of our ancestors: let us be wise, orderly and peaceful, if it is not so, it must be regretful of income first, regret then useless, because what causes personal suffering is the result of one's own actions". ('Arifin, 1988)

\section{Socio-Political Context}

Associated with the titi prey, Tanbih was signed by KH. Ahmad Shohibul Wafa 'Tajul 'Arifin, at Patapan Suryalaya, February 13, 1956, a situation in which national values, were being helped by a stumbling block with efforts to establish the Islamic State of Indonesia (NII). Strengthening religious relations with the state as in the Tanbih text, finding the right momentum, and is a smart and wise answer to the context of the political situation that occurred at that time. The relationship between Islam and the State in the explanation of Gusdur - a prominent student of Abah Anom and later President of the Republic of Indonesia - said that: Islam does not know the doctrine of the state. In the matter of the form of state, according to him, it does not have standard rules. This depends on the country concerned whether to use the model of democracy, theocracy or monarchy. The most important thing for Gusdur is the fulfillment of three criteria, namely: first, promoting the principles of deliberation. Second, uphold justice. Third, there is a guarantee of freedom (al-huriyyah) (Santalia, 2016).

The religious formalization movement in the form of establishing a religious state (Islam) in the life of the state basically had also appeared at the beginning of Indonesian Independence. The movement to establish a religious state was not completed after the agreement of the Pancasila ideology with the precepts of the Almighty Godhead between Mohammad Hatta and KH Abdul Wahid Hasyim et al. Muzakkar in Sulawesi, and Daud Beureueh in Aceh. (Dahlan, 2014). Abah 
Anom, as someone who was a religious reformer and at the same time loved the motherland, did not dissolve in providing support for the DI / TII movement, who wanted a form of theocratic NII, as Kartosuwiryo fought for with his base in West Java. Abah Anom gave support to the building of the mandate of Indonesianism which was developed into a democratic state since it was proclaimed by Soekarno-Hatta, August 17, 1945, for the sake of the attitude of the consort to practice the Tanbih which his father had inherited in maintaining harmony in Islamic values and Indonesian-ness. Abah Anom seems to prefer those who fight for an Indonesian state based on Islamic values (Islamic Values-Based State), as the struggle of Islamic Nationalists, both in BPUPKI / PPKI and in the Constituent Assembly, is indeed not to establish an Islamic state (Islamic State) ) (Suyuthi, 2001)

After undergoing a very long period, Sheikh Abdullah Mubarok as the first caliph of TQN in Tasikmalaya with all his success, he finally returned to Rahmatullah on January 25,1956 . Sheikh Abdullah bin Nur Muhammad returned calmly and in full conscious condition at the age of 120 years. During Abah Anom, the situation in West Java was very bad due to the disorder of DI / TII Kartosuwiryo (1949-1962). For 13 years DI / TII continuously attacked Suryalaya Islamic Boarding School. For 13 years, KH. Shohibul Wafa 'Tajul' Arifin / Abah Anom can defend Suryalaya from attacks even in bad situations Abah Anom has tried to build various agricultural facilities and infrastructure such as irrigation channels for the creation of government programs in food self-sufficiency. (Ma'mun, 2018).

As a leader of the Ummah with the support of an increasingly strong and growing TQN network, Abah Anom is very realistic about the ideological basis and form of the Indonesian state which does not choose an Islamic state. His great energy was instead concentrated to provide support for the sovereignty of the Republic of Indonesia by filling independence with real work. It seems that both Abah Sepuh and Abah Anom belong to the Islamic Nationalist category which they express a lot through symbolic language. If the color of the Indonesian flag is red and white, historical facts show that since the establishment of TQN Suryalaya in 1905 or 40 years before Indonesian independence, the symbol of the butterfly in red and white has been worn on the right breast of Abah Sepuh's shirt in the form of pins made of aluminum and he always uses it on official occasions (Kurnianto, 2016).

Regarding Suryalaya's acceptance of Pancasila, in the PPKI session, 18 August 1945, several important changes were discussed in the Preamble (derived from the Jakarta Charter text) and the body of the Basic Law. A very important change in the Preamble is a clause: "Awaken to the Godhead with the obligation to carry out Islamic law for its adherents", changed to, "Based on the Godhead of Godhead". According to Alamsyah Prawiranegara when he was Minister of Religion during the New Order, it was often said that the present Pancasila was a "gift" or "sacrifice" for Muslims for the unity and independence of the Indonesian Nation, by crossing out seven words behind the Godhead, and replacing them with three words, The Almighty. This awareness and acceptance of the Muslim community means a great deal to the New Order government to pave the way towards the acceptance of Pancasila as the only principle for all social and political organizations, including Islamic organizations in 1985 (Suyuthi, 2001). As a practicing tarekat, TQN Suryalaya does not dispute the status of Pancasila as the sole principle.

This single principle has indeed received mixed responses among Indonesian Muslims. As the largest religious social organization, the Nahdlatul Ulama gave a positive response. Acceptance of Pancasila as the state ideology led by Gusdur and KH. Amad Siddiq, at least for two reasons namely; First, Islam is a religion of nature. As long as a value does not conflict with Islamic beliefs, 
it can be directed to be in harmony with the goals in Islam. When Islam is accepted by society, it does not have to replace the values contained in it, but to be perfect. (Santalia, 2015). Within Suryalaya Islamic Boarding School's own environment, the Pancasila single principle is integrated with the universal values of the Five Pillars of Islam. The butterfly in the Suryalaya document, framed in a pentagon that points to the meaning of two things; first, the sole principle of Pancasila; and second, meaning the five pillars of Islam, namely the creed, prayer, zakat, fasting, and pilgrimage. (Kurnianto, 2016)

The TQN Suryalaya butterfly wing is yellow, illustrating the TQN Suryalaya's concern for the development problems faced by the New Order government (at that time) which was politically supported by the large political group Golongan Karya with a symbol of the magnitude of the banyan tree in yellow, although in the context of this support, the TQN Suryalaya tariqah strives to remain neutral and not dissolve in political support, but is engrossed in real work to contribute its capabilities and expertise. Empirical evidence of the involvement of concern is that around the 80s had succeeded in building irrigation in the Pagerageung District area which was later called DAM Nur Muhammad who was able to flow through hundreds of hectares of rice fields and residents' fields around the Pagerageung District area. Their real work has also been able to move the surrounding community to care about the surrounding environment in the headline of the greening program and to deliver the Suryalaya TQN order to get an award from the Government; Kalpataru (1984). (Kurnianto, 2016) During Abah Anom's leadership, environmental preservation efforts continued because in the 1980s too, he pioneered clove cultivation. Clove prices on the market then dropped. Many farmers are asked to cut down clove trees which is very detrimental to them, including in Suryalaya. Abah Anom then took the command line so that the clove trees were replaced with teak trees so that in the early 1990s, they succeeded in planting 2000 teak trees and successfully maintained until now (Widarda, 2013).

\section{Philosophical Reflections}

If philosophy is an exploitation of the nature of reality that exists in human life and encompasses the nature of humanity itself, the nature of the universe, even the nature of God, (Bakker \& Zubair, 1990) then what Abah Sepuh wrote in Tanbih - although it must be carefully noted for say it as a philosophical text - very loaded with philosophical content. In other words, Tanbih with the themes of religious relations with the state, the ethical dimension of universal humanity, the seeding of tolerance values, as well as the firmness of faith, has philosophical values that are very deep and holistically related to human relations with others (intra human), human relations with God (supra human), as well as with the natural environment (infra human).

The whole of Tanbih is to talk about ethical aspects from an Islamic perspective. When religion talks about ethical topics, it tries to motivate and inspire people to obey the values and norms that they have received based on faith. When philosophy talks about ethical topics, it argues, meaning that it tries to show that an action must be considered good or bad, only by showing rational reasons (Bertens, 2001)

That is the difference between the religious approach and philosophy when speaking of ethical dimensions. In the context of religious relations with the state in the Tanbih Text, even though it contains philosophical values about good and bad in the behavior of religious and state relations, it is based on a central theme of the power of faith. But, although starting from a different perspective when talking about ethical topics, does not mean that in the ethical field, there is no 
close relationship between religion and philosophy. That relationship can be approached in terms of philosophy and religion. (Bertens, 2001).

\section{CONCLUSION}

Viewed in terms of philosophy, the relationship of religion with the state in the Tanbih Text will be influenced by the religiosity of Abah Sepuh as its author, which on religious grounds will bring salvation of human life to avoid God's hell and go to His eternal paradise. That is the same as Saint Augustine in the West who wrote the City of God, and splits the reality into City of God and City of the Devil, which were strongly influenced by the Christian faith. In the Tanbih Text we can also read messages that are reflective and critical. Because it is based on absolute religious values, that obedience to religion must take precedence over obedience to temporal temporal space in the form of a state. All forms of constitution and state regulations can only be followed as long as they do not conflict with the basic values of religion.

The conclusion of this study, there is a strong relationship between religion and the state in the Tanbih Text and can be the basis for maintaining the sovereignty of the NKRI with a solid religious outlook and expressions laden with philosophical values. This study provides recommendations for further research related to the relationship of religion with the state in order to strengthen the mandate of Indonesians amid the development of ideology that threatens state sovereignty, which has occurred since the beginning of independence until now 


\section{REFEREENCES}

Arifin, A.S.W. T, (1988), Tanbih, Tawasul, Manaqib, Bahasa Indonesia, Bandung, Wahana Karya Grafika.

Baidlowi, AB, (2020) Implementasi Tanbih TQN Suryalaya Dalam Kehidupan Bermasyarakat di Pondok Pesantren Al-Kautsar Pademawu Pamekasan, Jurnal al- Ulum: Jurnal Pemikiran dan Penelitian ke-Islaman Vol 7 No 1 (2020)

Bakker, Anton \&Zubair, A.Ch. (1990), Metodologi Penelitian Filsafat, Yogyakarta, Kanisius.

Bertens, 2001, Etika, Jakarta, Gramedia.

Dahlan, Moh, (2014), Hubungan Agama dan Negara Di Indonesia, Analisis, Jurnal Studi Keislaman, Vol. 14, No 1 (2014).

Gunawan, Djarlis (2016), Cultural Strategy of Pesantren Suryalaya-Tasikmalaya as Center of Islamic Studies in Facing Industrial Era 4.0, Jurnal Pengabdian Kepada Masyarakat, Vol. 2 No. 7 (2018)

Hidayat, 2016, Tanbih: Harmoni Dalam Bingkai Islam dan Kearifan Tradisi, Prosiding Seminar Nasional Sastra dan Budaya Denpasar, 27-28 Mei 2016.

Kurnianto, 2016, Kajian Makna Simbol Kupu-Kupu Terbang ke Langit pada Tarekat Qâdirîyah Naqshabandîyah Suryalaya Tasikmalaya, Marâji, Jurnal Ilmu Keislaman, Vol 2. No. 2 (2016).

Ma'mun, S. (2018), TQN, Diamalkan, Diamankan, Dilestarikan, academic-edu.

Mikail, Kiki. "PEMILU DAN PARTAI POLITIK DI INDONESIA: Menanti Kebangkitan Partai Politik Islam Di Tahun 2019”. Tamaddun: Jurnal Kebudayaan dan Sastra Islam 15, no. 1 (April 7, 2016): 107-148. Accessed December 31, 2020. http://jurnal.radenfatah.ac.id/index.php/tamaddun/article/view/444.

Misbach, Irwan, (2018), Strategi Dakwah Perspektif Informal Populer (Telaah Dakwah Kh. A Shohibul Wafa Tajul Arifin), Jurnal Dakwah Tabligh, Vol. 17 No. 2 (2016).

Pujiastuti, T (2016), Perkembangan Tarekat Qadiriyyah-Naqshabandiyyah di Pesantren Suryalaya, El-Afkar, Jurnal Pemikiran Keislaman dan Tafsir Hadits, Vol. 5 No. 2 (2016).

Rohimat, AM, (2017), Etika Politik Dalam Naskah Tanbih (Wasiat Etika Politik Dari Mursyid Tarekat Qodiriyyah Naqsyabandiyah Suryalaya Terhadap Murid-Muridnya), In Right, Vol. 2 No. 1 (2012)

Samsulbassar, Agus, 2018, Eksistensi Pondok Pesantren Berbasis Tarekat Dalam Era Global dan Digital, Jurnal Pendidikan Islam Indonesia, Vol. 3 No. 1 (2018).

Santalia, Indo, (2018), K.H. Abdurrahman Wahid: Agama Dan Negara, Pluralisme, Demokratisasi, Dan Pribumisasi, al-adyaan, Jurnal Sosial Agama, Vol. 1 No. 2 (2015).

Sayyi, A. (2017), Wasiat Pendidikan Sufistik Dalam Naskah Tanbih Mursyid Tarekat Qodiriyyah wa Naqsyabandiyyah Suryalaya (Telaah Pemikiran Guru Mursyid TQN Suryalaya), Fikrotuna, Jurnal Pendidikan dan Manajemen Islam, Vol. 5 No. 1 (2017)

Suprayogo, Imam \& Tobroni, (2003), Metodologi Penelitian Sosial Agama, Bandung, Remaja Rosda Karya.

Suyuthi, 2001, Politik Tarekat Qadiriyah wa Naqsyabandiyah Jombang, Hubungan Agama, Negara, dan Masyarakat, Yogyakarta, Galang Press. 
Syukri, A. (\&nbsp;). Malay Muslims Patani Insurgency Pattern in the Post-Revolution 1932. Jurnal Studi Sosial Dan Politik, 3(2), 146-155. https://doi.org/https://doi.org/10.19109/jssp.v3i2.4400

Widarda, Dodo, (2013), Tasawuf Bagi Rekonstruksi Masa Depan Kemanusiaan: Sudut Pandang TQN Suryalaya, Tasikmalaya, Fakultas Syariah IAILM Suryalaya. 